\title{
H. 1142 ( M. 1729- 1730) TARİHLİ BÜYÜK KALE DEFTERİNE GÖRE HEMEDAN KALESI PIYYADE VE SÜVARİ LEVENDLERİ
}

\author{
Infantry and Mounted Troops of Hemedan Castle Acording To The Grand Book of Castle \\ Dating Back To 1142 Hegeria (1729-1730 Ad)
}

\section{Uğur DEMLİKOĞLU*}

\begin{abstract}
ÖZET
Osmanlı-İran savaşlarının çok çetin geçtiği 1729-1730 tarihleri arasında Osmanlı Devleti, Hemedan Kalesi'ni İran'dan geri almak maksadıyla piyade ve süvari levendleri göndermiştir. Bu piyade ve süvari levendleri mirî olup, Kilis, Diyarbakır, Mardin ve Anadolu'nun muhtelif yerlerinden temin edilmiş ve Hemedan Kalesi'ne gönderilmiştir. Piyade ve süvari levendlerinin tahririne mübaşirler görevlendirilmiş ve bu askerlerin başlarına da zabit olarak bir başbuğ tayin edilmiştir. Gerek süvari gerekse piyade levendleri bir bayrak altında 50'şer askerden oluşmuştur.

Süvari ve piyade levendlerine ulûfe, bahşiş, muhtelif sayıda bargir, çeşitli mühimmat ile bakırdan yapılmış ev eşyaları ve tayinat verilmiştir. Süvari ve piyade levendlerinin her birine verilen ulûfe miktarında bir değişiklik olmamış; ancak süvariler piyadelere nazaran daha fazla bahşiş, bargir, mühimmat ile tayinat dağıtılmıştır.

Hemedan Kalesi'ne gönderilen piyade askerlerinin sayısı süvarilere göre daha fazladır. Kaleye 3.500 piyade neferi gönderilmiş iken, süvari levendleri sadece 1.500 kişi olmuştur. Süvari levendlerinin piyadelere göre Osmanlı hazinesine bıraktığı mali külfet daha fazla olmuştur.
\end{abstract}

Anahtar kelimeler: Hemedan Kalesi, Piyade, Süvari, Levend, Ulûfe, Mühimmat

\begin{abstract}
The Ottoman Empire sent infantry and cavalry troops with the aim to take back the Hemedan Castle from the Persians in the tough wars between the Ottomans and Persians between the years 1729- 1730. These infantry and cavalry troops were public and were gathered from Kilis, Diyarbakir, Mardin, and various places of Anatolia, and were sent to the Hemedan Castle. Summoners were charged with the records of infantry and cavalry soldiers, and a commander was appointed as officer over the soldiers. Teams of 50 soldiers were composed of infantry and cavalry soldiers.
\end{abstract}

The cavalry and infantry soldiers received ulufe (service pay in Ottoman empire), gratuity, various numbers of pack animals, various ammunition, copper domestic utensils, and nutrition. The amount of the ulufe which was granted to cavalry and infantry soldiers wasn't changed; however, the cavalry received more gratuity, pack animals, various ammunition, and nutrition than the infantry.

The number of infantry soldiers who were despatched to the Hemedan Castle was more than the number of cavalry soldiers. 3.500 infantry soldiers were despatched to the castle, while the number of cavalry soldiers was only 1.500. The cost of cavalry soldiers was a higher for the Ottoman treasury.

Keywords: the Hemedan Castle, Infantry, Cavalry, Ulufe, Ammunition

\section{GíRiş}

Hemedan, İran'ın batısında Elvend Dağı'nın eteğinde Kuruçay, Abbasâbâd ve Sûmine 1rmaklarıyla sulanan verimli bir ovada bulunmaktadır. Deniz seviyesinden 1.800 metre yüksekliğe sahip

\footnotetext{
* Dr. Milli Eğitim Bakanlığında Tarih Öğretmeni, ugurtarih@hotmail.com
} 


\section{F.Ü. Sosyal Bilimler Dergisi 2013-24/1}

ve üç tarafı dağlarla çevrilidir ${ }^{1}$. Doğu Akdeniz ile Batı İran platosunu birbirine bağlayan yolun üzerinde oldukça stratejik bir konumdadır ${ }^{2}$.

Hemedan; Kazvin, Kirmanşah ve Bağdat yolunun üzerinde kendi adını taşıyan eyaletin merkezidir. Kuzeyinde Azerbaycan'ın Hamsasi ve Kazvin eyaletleri, batıda Kirmanşah, güneyde Irak ve Malayir, doğuda ise Halacistan sancağı ile sınırlanmış dağlik bir yerdir. Tarih boyunca Mezopotamya'dan Kafkasya, Horasan ve Türkistan'a giden ticari ve askeri yolun en önemli güzergâhı olmuştur ${ }^{3}$. Hemedan bir bilim ve kültür merkezi olduğu kadar aynı zamanda bir ticaret merkezi konumundaydı. İranlılar Hemedan üzerinden Bağdat'a ve oradan da Mekke'ye ulaşmaktaydı ${ }^{4}$.

Safeviler, stratejik konumundan faydalanarak Osmanlı Devleti'ne karşı Hemedan'ı askeri bir üst olarak kullandılar. Kanuni Sultan Süleyman 1534 yılında Tebriz'den Bağdat üzerine yürüdüğünde Hemedan yolundan geçmiş, III. Murat döneminde Vezir Cigala-zade Sinan Paşa Hemedan Kalesi'ni ele geçirmişti ${ }^{5}$.

Osmanlı Devleti, Hemedan Kalesi'ni alarak İran'ın Bağdat'a inmesine engel olmak, Kafkasya, Horasan ve Türkistan ticaretini kontrol etmek istemekteydi.

1639 tarihinde imzalan Kasr-1 Şirin antlaşmasıyla Osmanlı- Safevi ilişkileri uzun bir sükûnet dönemine girmişti. Ancak, 1722 tarihinde İran'ın Afganistan'a girmesi üzerine ilişkiler yeniden gerginleşti. Damat İbrahim Paşa, İran'ın Afganistan'ın eline geçmesini istemiyordu ve sınır komutanlarına emirler göndererek Revan, Tebriz, Gence ve Tiflis'in alınmasını istiyordu' ${ }^{6}$. Mir Mahmud Han'ın İsfahan'1 ele geçirmesi üzerine Osmanlı Devleti İran'a karşı savaş ilan etti. Osmanlı ordusu Kafkasya, Azerbaycan, Irak-1 Acem olmak üzere üç koldan harekete geçerek Tebriz, Revan, Gence ve Hemedan gibi önemli yerleri işgal etmeyi hedefledi ${ }^{7}$. Erzurum Valisi Vezir Silahdar İbrahim Paşa Tiflis'in fethi için Erzurum'dan Kars'a doğru hareket etti ${ }^{8}$. Silahdar İbrahim Paşa komutasında ilerleyen Osmanlı ordusu, 1723 baharında Gürcülerin yardımı ile Gori ve Tiflis'i ald1 ${ }^{9}$.

Kafkasya seraskeri Ârifi Ahmet Paşa Erivan'1, Van Valisi Köprülüzade Abdullah Paşa Tebriz'i, Bağdat Valisi Eyyüblü Hasan Paşa Kirmanşah'1 almak üzere harekete geçmişti. Hasan Paşa 16 Ekim 1723 'te Kirmanşah, 12 Kasım 1723'te de Erdelan Eyaletini ele geçirdi. Köprülüzade Abdullah Paşa Selmas, Hoy, Çors ve Merend şehirlerini ele geçirdi. Hoy şehrini alan Osmanlı ordusu Tebriz önlerine gelerek şiddetli direniş gösteren bu şehri de ele geçirdi ${ }^{10} 1$ Eylül 1724 tarihinde 2 ay süren bir kuşatmanın ardından Hemedan Kalesi Osmanlı ordularının eline geçti ${ }^{11}$. Bu gelişmeler üzerine II. Tahmasb tahtan indirildi ve yerine Eşref Han hükümdar oldu ${ }^{12}$. Eşref Şah'ın ordusu ile Bağdat valisi Ahmed Paşa'nın komutasındaki Osmanlı ordusu Kasım 1726 tarihinde Nihavend yakınlarında savaştılar. Ancak yapılan savaşta Osmanlı ordusu disiplinsizce davranışlar göstermiş ve başarılı olamamıştı. Ahmed Paşa Hemedan'a dönmek zorunda kaldı. Osmanlı ordusu Hemedan'a büyük bir kuvvet göndermiş; ancak İran Hükümdarı Eşref Şah, Şehzade Tahmasb'ın

\footnotetext{
${ }^{1}$ Tahsin Yazıc1, "Hemedân", DİA, C. XVII, İstanbul, 1988, s. 183.

2 İlker Kulbilge, 18. Yüzyılın İlk Yarısında Osmanl- İran Siyasi İlişkileri (1703-1747), Ege Üniversitesi Sosyal Bilimler Enstitüsü Tarih Anabilim Dalı Yeniçağ Tarihi Bilim Dalı (Basılmamış Doktora Tezi) İzmir, 2010, s. 86.

${ }^{3}$ Mirza Bala, "Hemedân", IA, C. 5/1, Eskişehir, 2001, s. 420.

${ }^{4}$ Yazic1, s. 184.

${ }^{5}$ Bala, 424.

${ }^{6}$ İsmail Hakkı Uzunçarşılı, Osmanlı Tarihi, C. IV, Türk tarih Kurumu Basımevi, Ankara, 1999, s.174.

${ }^{7}$ Abdurrahman Ateş, Avşarlı Nadir Şah ve Döneminde Osmanll- İran Mücadeleleri, Süleyman Demirel Üniversitesi Sosyal Bilimler Enstitüsü Tarih Anabilim Dalı, Doktora Tezi, Isparta, 2001, s. 41.

${ }^{8}$ Küçük Çelebizâde İsmail Asım, Asım Tarihi, İstanbul, 1284, s. 45.

${ }^{9}$ Fahrettin Kırzıoğlu, Kars Tarihi, İstanbul, 1953, s. 538.

${ }^{10}$ Münir Aktepe, 1720- 1724 Osmanll- Iran Münasebetleri ve Silahşör Kemânî Mustafa Ağa’nın Revan Fetih-nâmesi, İstanbul, 1970, s. 22

${ }^{11}$ Joseph Von Hammer, Büyük Osmanlı Tarihi, C. VII, ( Çev. Vecdi Bürün), İstanbul, 1991, s. 316.

${ }^{12}$ Uğur Kurtaran, "Yeni Kaynakların Işı̆̆ında Sultan I. Mahmud Dönemi Osmanlı İran İlişkileri (1731- 1747)", History Studies, Volume 3/3, 2011, s.182.
} 
kendisine karşı taraftar bulması ve Nadir'in İran'da güçlü bir şekilde ortaya çıkmasını kendi geleceği açısından sıkıntılı görmüş ve Osmanlı Devleti ile barış yapmaya mecbur kalmıştı ${ }^{13}$.

Osmanlı Devleti için İran savaşları ekonomik bir yük olmuş ve Osmanlı maliyesine 50 milyon akçeden fazla bir yük getirmişti ${ }^{14}$. Bağdat Valisi Ahmet Paşa'nın Osmanlı- İran arasında arabuluculuk yapmasıyla iki taraf arasında 4 Ekim 1727 tarihinde Hemedan Antlaşması imzalan$\mathrm{d}_{1}{ }^{15}$. Dokuz maddeden oluşan bu antlaşmanın en önemli yanı; Kirmanşah, Hemedan, Erdelan, Lûristan, Nihavend, Tebriz, Azerbaycan, Gence, Karabağ ve Revan eyaletlerinin Osmanlı topraklarına katılmış olmasıdır ${ }^{16}$.

1726 yılının Eylül ayında II. Tahmasb'ın hizmetine giren Nadir, "Tahmasb Kulu Han" unvanını aldıktan sonra kendi kuvvetlerinin yanında II. Tahmasb'ın da kuvvetlerini alarak doğudaki Afgan tehlikesini ortadan kaldırmak için harekete geçti ${ }^{17}$. Nadir, 1727 yılında Osmanlı Devleti ile yapılan antlaşmaları geçersiz saydı. Nihavend ve Hemedan'a gönderdiği memurlar vasıtasıyla bölge halkını Osmanlı Devletine karşı kışkırtı. 1730 yılında İstanbul'a gönderdiği Rıza Kulu Han aracılığıyla da Osmanlı ordusuna esir düşmüş askerlerinin ve Osmanlı işgali altında bulunan İran topraklarının iadesini istedi. Nadir, elçisinin geri dönüşünü beklemeden Nihavend Kalesi'ni 1 Temmuz 1730 tarihinde, Hemedan'1 7 Temmuz da, Tebriz'i de 12 Ağustos'ta ele geçirdi. 1730 tarihinde İstanbul'da çıkan Patrona Halil isyanıyla Osmanlı Devleti'nin içinde bulunduğu bunalım, İran sınırındaki hudut komutanları arasındaki anlaşmazlıklar Nadir'in işini kolaylaştırmış ve topraklarını genişletme imkânı elde etmiştir ${ }^{18}$. Osmanlı Devleti'nin başına I. Mahmut'un geçmesiyle Osmanlı orduları toparlanarak Irak ve Azerbaycan tarafindan taarruza geçti ${ }^{19}$. Bağdat valisi ve İran seraskeri Ahmet Paşa ile Erzurum Valisi ve Revan seraskeri Ali Paşa'ya Irak-1 Acem taraflarında iki koldan taarruza geçmeleri yönünde emirler gönderildi. ${ }^{20}$.

Şah II. Tahmasb Revan, Gence ve Nahçivan'ı almak maksadıyla Tebriz'den harekete geçti ise de Osmanlılar Revan'1 savunmak için gerekli önlemleri aldılar. Anadolu, Kars ve Adana beylerbeylerine Revan'a asker ve mühimmat gönderilmesi için emirler gönderildi ${ }^{21}$. Osmanlı ordusu Hemedan yakınlarındaki Kurican mevkisinde İran ordusunu bozguna uğrattı. Şah Tahmasb maiyetindeki 500 kişi ile birlikte kaçmak zorunda kaldı. 17 Eylül 1731 tarihinde Osmanlı orduları Hemedan'1 tekrar ele geçirdiler ${ }^{22}$.

1729- 1730 ( H. 1142) tarihleri arasında Osmanlılar tarafından Hamedan Kalesi'ne yoğun bir piyade ve süvari levendi nakledildiği görülmektedirr ${ }^{23}$.

\footnotetext{
${ }^{13}$ Münir Aktepe, "Vak'anüvis Raşid Mehmet Efendi'nin Eşref Şah Nezdindeki Elçiliği”, Türkiyat Mecmuası, XII, Sayı: 11,1955 , s. 163.

${ }^{14}$ Johann Wilhelm Zinkeısen, Osmanlı Imparatorluğu Tarihi, C. V, İstanbul, 2011, s. 431

${ }^{15}$ M. Münir Aktepe, "Nadir Şah'ın Osmanlı Padişahı I. Mahmud'a Gönderdiği Taht-1 Tavus Hakkında”, Tarih Dergisi, Say1: 28- 29, İstanbul, 1975, s. 113.

${ }^{16}$ Zinkessen, Osmanlı Imparatorluğu Tarihi, C. V, s. 431, 432.

${ }^{17}$ Ateş, s. 41.

${ }^{18}$ V. Mınorsky, "Nadir”, IA , C. IX, Milli Eğitim Bakanlı̆̆ı Devlet Kitapları, Eskişehir, 2001, s.22

${ }^{19}$ Şem'dânî- Zade Fındıklılı Süleyman Efendi, Mür'i’t Tevârih, C. I, (Haz. Münir Aktepe), İstanbul, 1976, s. 1- 3; V. Minorsky, "Nadir", IA, C. IV, s. 23.

${ }^{20}$ Uzunçarş11, Osmanlı Tarihi, C. IV, s. 220

${ }^{21}$ Raif İvecan, Osmanlı Hâkimiyetinde Revan (1724- 1746), Marmara Üniversitesi Türkiyat Araştırmaları Enstitüsü Türk Tarihi Anabilim Dalı Yeniçağ Tarihi Bilim Dalı, Basılmamış Doktora Tezi, İstanbul, 2007, s. 35.

${ }^{22}$ Uzunçarşıll, Osmanlı Tarihi, C. IV, s. 220.

${ }^{23}$ Levend kelimesi; bikâr, kâhil, tembel, zâni, ayyaş gibi anlamlara gelebildiği gibi şagirt, hizmetkâr, saraydar, 1rgat gibi anlamlara da gelmektedir. (Mütercim Âsım Efendi, Burhân-ı Katı, (Çev. Mürsel Öztürk, Derya Örs), Türk Dil Kurumu Yayınları, Ankara, 2009, s. 570). Farsçada nefsine düşkün, başıboş, tembel, işsiz, ayyaş, kabadayı anlamında olan Levend tabirini Venedikliler de kullanmıştır. Venedikliler, doğudaki ahaliden temin ettikleri askerlere bu ismi vermiştir. Levend aynı zamanda Osmanlı bahriye ordusunda bulunan askerlerin bir çeşidine verilen isimdir. (Mehmet Zeki Pakalın, Osmanlı Tarih Deyimleri ve Terimleri Sözlü̆̆̈̈, C. II, Milli Eğitim Basımevi, İstanbul 1983, s. 358). Levend, gemi tüfekçisine verilen isim de olmuştur. (Ahmet Vefik Paşa, Lehçe-i Osmani, Türk Dil Kurumu Yayınları, Haz. Recep Toparl, Ankara, 2000, s. 703). Denizlerde korsanlık faaliyetinde bulunan ve daha sonra muharip güç olarak Osmanlı donanmasına katılan güçlü, kuvvetli Türk denizcilerine de levend denilmekteydi. (Bkz.İsmail Hakkı Uzunçarşı1ı,
} 


\section{F.Ü. Sosyal Bilimler Dergisi 2013-24/1}

Bu çalışmada, 1729- 1730 (H. 1142) tarihli bir kale defteri kaynak olarak kullanılmak suretiyle Hemedan Kalesi'nde bulunan süvari ve piyade levendleri tespit edilmeye çalışılmıştır ${ }^{24}$.

\section{Piyade ve Süvari Levendlerinin Sayısı, Ulûfe ve Bahşişleri}

Hemedan'ın muhafazası için Kara Çorlu Osman'a gönderilen bir hükümde; 1.000 kişiden oluşan mirî piyade levendinin Diyarbakır'ın ekrâd (Kürt) cemaatinden temin edilmesi ferman olunmuştur. Alınacak levendlerin daha önceden harbe katılmış, tecrübeli ve faydalı olanlardan seçilmesi istenmiştir ${ }^{25}$. Bu piyade levendlerinin tahrir edilmesi için de Silahşor Şehmuz- zâde Mustafa adında bir mübaşirir ${ }^{26}$ tayin edilmiştir. Kaydedilen bu 1000 kişilik piyade levendi Bağdat valisi ve Hemedân Seraskeri Kara Ahmet Paşa'nın maiyetine memur kılınmıştır. Bunlar 20 adet bayraktan müteşekkil olup, her bir bayrak 50 neferden oluşuyordu ${ }^{27} .20$ bayraktan oluşan bu bin kişilik piyade levendlerine Kara Çorlu Osman başbuğ ${ }^{28}$ olarak atanmıştır ${ }^{29}$. Bunların ulûfeleri ${ }^{30}$ üç aylık değil aylık olarak hesaplanmış ve her bir nefere aylık 2,5 guruş verilmiştir. Bunların 6 aylık toplam masrafları 15.000 guruş etmekteydi. Bu ücrete ek olarak birliğin olağandışı harcamaları için de 1.500 guruş daha verilmiş ve böylece levendlere toplamda 16.500 guruşluk bir ödeme yapılmışıır ${ }^{31}$.

Piyade levendlerine ulûfelerinin yanı sıra bahşiş ${ }^{32}$ de verilmiştir. Hemedan Kalesi’nde görevlendirilen levendlerin her birisine 12 guruş bahşiş takdir edilmiştir. Bunların bahşiş ve ulûfelerinin toplamı 28.500 guruşa ulaşmışıır ${ }^{33}$.

Osmanlı Devletinin Merkez ve Bahriye Teşkilatı, Türk Tarih Kurumu, Ankara, 1948, s. 480). Levendlerden hem kara hem de deniz muharebelerinde faydalanılmışırı. Denizlerde görev yapan levendlerin bir kısmı, korsan gemilerinin savaşçı ihtiyacını karşılarken bir kısmı da XVII. yüzyıldan sonra sefer zamanında gemilerin savaşçı ihtiyacının karşılanması için sahilde bulunan ahaliden temin edilip tüfekçi askerler olarak gemide görevlendirilmiştir. (Mithat Sertoğlu, Osmanlı Tarih Lügâtı, Ankara, 1999, s. 199). Deniz levendleri genellikle eşkiyalık, isyan, soygunculuk ve gasp gibi olumsuz hareketleriyle tanınmışlardır. (Mustafa Akdağ, Türkiye'nin İktisadî ve İçtimaî Tarihi 1453- 1559, C. II, Ankara, 1999, s. 326). Kara levendleri de deniz levendleri gibi XVI. yüzyıla kadar başıboş, avare, hırsız, soyguncu insanlar gibi görülmüştür. (Ahmet Akgündüz, Osmanlı Kanunnameleri ve Hukuki Tahlilleri, C. V, İstanbul, 1992, s.59). 17. yüzyıldan sonra saruca, sekban bölükleriyle beraber bir beylerbeyinin maiyetinde görev almalarıla birlikte önemleri ortaya çıkmıştır. Kapılı ve kapısız olarak nitelendirilmişlerdir. Kapılı levend; bir vezirin veya beylerbeyinin emrinde hizmette bulunan levendlere verilen isimdir. Kapısız levend ise kapılı levendlerin bağlı oldukları vezir ve beylerbeyinin azledilmesi halinde boş kalmaları ve herhangi bir beye kapılıncaya kadar görevde bulunmayan levendleri ifade etmekteydi. (Sertoğlu, s. 199; Ahmet Akgündüz, Osmanlı Kanunnameleri ve Hukuki Tahlilleri, C. IX, İstanbul, 1992, s. 214). Kapısız levendlerin ne zaman ve ne şekilde ortaya çıktığı hakkında bilgiler kesin olmamakla birlikte Anadolu'da büyük bir huzursuzluk çıkarmışlardır. Mücteba İlgürel "Levend", DİA, C. XXVII, Ankara, s. 149). 16. yüzyılda Anadolu'da büyük bir nüfus patlaması yaşanmış, zirai üretim bu nüfus artışına yeterli gelmemiş, Anadolu'da yersiz, yurtsuz birçok insan devlet kapısında kapı halkı olmak ya da sınır kalelerinde levend ve gönüllü olma mecburiyetine girmişti. Mustafa Akdăg, Celali İsyanları, Ankara, 1999, s. 153. Levendler, ulûfe ve bahşişleri verilmek suretiyle geçici olarak bir vali ya da beylerbeyinin maiyetinde savaşa katılmaktaydı. Bu çeşit levendlere miri levendât denilmekteydi. (Sertoğlu, s. 358). Bunların ihtiyaçları doğrudan devlet tarafından karşılanmaktaydı. Mustafa Cezar, Osmanlı Tarihinde Levendler, İstanbul, 1965, s. 345. Levendler, piyade ve süvari olmak üzere iki çeşittir. Bkz. Pakalın, Osmanlı Tarih Deyimleri ve Terimleri Sözlü̆̈̈̈, C. II, s. 360. Osmanlı toprak sisteminin bozulması, tımarlı sipahiliği de çöküntüye uğratmış ve devlet ihtiyaç duyduğu askerleri levendlerden karşılamıştır. (Cezar, s. 345).

${ }^{24}$ Söz konusu defter Başbakanlık Osmanlı Arşivi Bab-ı Asafi tasnifinde ve 32.459 numarada bulunmaktadır. Bu deftere, Anadolu'dan özellikle de Diyarbakır, Mardin, Kilis, Döğerli ve Bucak Cemaatleri arasından tahriri yapılıp Hemedan Kalesi'ne gönderilen piyade ve süvari levendlerin sayısı ile bahşiş, ulûfe, tayinat, mühimmat, bargir, çeşitli ev eşyaları ve bunlar için yapılan masraflar kaydedilmiştir. BOA, D. BKL. d. 32459, s. 1- 24.

${ }^{25}$ BOA, D. BKL. d. 32459, s. 6.

${ }^{26}$ Mübaşir; Arapça'da bir işe başlayan, başlayıcı anlamına gelmekte olup, devlet tarafından zaruri görülen bir iş için görevlendirilen memurdur. Pakalın, "Mübaşir”, Osmanlı Tarih Deyimleri ve Terimleri Sözlüğü, C. II, s. 592.

${ }^{27}$ BOA, D. BKL. d. 32459, s. 6.

${ }^{28}$ Başbuğ: Savaş dönemlerinde bir birliğe kumanda eden komutana verilen rütbedir. Sertoğlu, s. 50.

${ }^{29}$ BOA, D. BKL.d. 32459, s. 6.

${ }^{30}$ Ulûfe; yeniçeri askerlerinin üç ayda bir aldıkları maaşa denilmekte ve bu resmi defterlerde mevâcib olarak geçmektedir. İsmail Hakkı Uzunçarşıl1, Kapukulu Ocakları, C. I, Türk Tarih Kurumu, Ankara, 1988, s. 411.

${ }_{31}$ BOA, D. BKL.d. 32459, s. 6.

${ }^{32}$ Bahşiş; Farsça'da büyükten küçüğe verilen hediye anlamına gelmekte olup, hizmetinden memnun kalınan hizmet erlerine emeğine karşıllk fazladan verilen para anlamına gelmektedir. CL. HUART, "Bahşış", İA, Milli Eğitim Basımevi, İstanbul, 1979, s. 238. 
Diyarbakır'dan temin edilen bu piyade levendlerinin dışında Anadolu'nun başka yerlerinden 500 kişilik piyade levendi de kaydedilmiştir. 6 Aralık 1729 tarihinde Hemedan Kalesi'ne gidecek Piyade levendlerin temini için Dergâh-1 Âli gönüllülerinden Mukataacı Mehmet Ağa mübaşir tayin olunmuştur. Bu levendlerin başbuğluğu ise Halife Şakird Osman Paşa'nın 2. bölükbaşçısı olan Mustafa getirilmiştir. Bu 500 kişiden oluşan piyade levendleri 10 bayraktan oluşmuş ve her bir bayrak 50 kişiden meydana gelmiştir ${ }^{34}$.

Piyade levendlerin her birine aylık 2,5 guruştan 1.250 guruş maaş verilmiş ve bunlar 6 ayın sonunda toplamda 7.500 guruş bir ulûfe almışlardır. Birliğin olağan dışı masraflarına ek olarak 750 guruş daha ulûfe verilmiştir. Böylece toplam ulûfeleri 8.250 guruşa ulaşmıştır. Bahşişlerine baktığımızda ise her bir nefere 12 guruşluk bir bahşiş verilmiş ve toplamda 500 piyade levendine 6.000 guruş bahşiş verilmiştir. 500 adet piyade levendinin ulûfe ve bahşişlerinin genel toplamı ise 14.250 guruş etmekteydi ${ }^{35}$.

Hemedan kaymakamı Abdurrahman Paşa'nın isteği üzerine, 2 Mart 1730 tarihinde Diyarbakır ve Mardin mahallerinden 2.000 piyade levendi kaydedilmiş ve Hemedan Kalesi'nin muhafazasına görevlendirilmiştir. 22 Nisan 1730 tarihinde Mardin Voyvodas ${ }^{36}$ Sadık'a gönderilen bir hükümde; Mardin, Diyarbakır havalilerinden ve diledikleri mahallerden 40 bayrak olmak üzere tahrir ettirilecek 2.000 neferin Hemedan Kalesi'ne bir an önce gönderilmesi istenmiştir ${ }^{37}$. Bu 2.000 kişilik Piyade levendlerinin her bir bayrağ 50 kişi olmak üzere 40 bayraktan oluşmaktayd ${ }^{38}$.

Diyarbakır ve Mardin taraflarında temin edilen 2.000 piyade levendinin her birine aylık 2,5 guruş maaş verilmiştir. Aylık ödenen ücret ise toplamda 5.000 guruş etmektedir. 6 ayın sonunda piyade levendlerine ödenen ücret 30.000 guruştur. Bunların ulûfelerine diğerlerinde olduğu gibi ek bir ücret verilmemiştir. Piyade levendlerine verilen bahşiş miktarlarına baktığımızda; 2000 neferin her birisine 12 guruşluk bir bahşiş verilmiş ve bahşişlerin toplamı da 24.000 guruş etmiştir ${ }^{39}$. Diyarbakır, Mardin ve Anadolu'dan temin edilip Hemedan Kalesi'ne gönderilen Piyade levendinin her birine verilen aylık 2,5 guruş ulûfe ile bir defaya mahsus olmak üzere verilen 20 guruşluk bahşiş miktarlarında herhangi bir değişiklik olmamıştır ${ }^{40}$.

Hemedan Kalesi'ne Piyade leventlerinden başka, süvari levendi de görevlendirilmiştir. Bu kale için 1729-1730 tarihleri arasında 1.000 nefer süvari levendi kaydedilmiştir. Süvari levendlerinin toplanılıp Hemedan'a gönderilmesi için Hassa silahşorlardan Kara Hasan görevlendirilmiştir. Başbuğluğuna ise Humus Beyi Ebubekir Paşa tayin olunmuştur. Bu 1000 nefer süvari levendinin Bağdat Valisi ve Hemedan seraskeri Vezir Ahmet Paşa'nın maiyetine katılmaları emredilmiştir.

Süvari levendleri, piyade levendleri gibi bayraklara bölünmüş, her bir bayrak 50 neferden oluşmuştur. Dolayısıyla 20 bayrakta toplam olarak 1.000 kişilik süvari levendi oluşmuştur.

Her bir süvari levendine aylık 2,5 guruş maaş verilmiştir. Dolayısıyla süvari levendine aylık toplamda 2500 guruş ve 6 ayın sonunda da 15.000 guruş ödenmiştir. Ayrıca bu ulûfelerine ek olarak daha önceki piyade levendlerinde olduğu gibi 1.500 guruş daha ek masraf ücreti verilmiş ve 6 ayın sonunda toplam 16.500 guruşluk bir ödeme gerçekleşmiştir. Verilen bahşiş miktarına baktığımızda; bu askerlere tıpkı piyade leventlerinde olduğu gibi bir defaya mahsus olmak üzere 20 guruş bir bahşiş verilmiş ve toplamda 20.000 guruşa ulaşmıştır. Ulûfe ve bahşişlerin toplamı ise

\footnotetext{
${ }^{33}$ BOA, D. BKL.d. 32459 , s. 6.

${ }^{34}$ BOA, D. BKL.d. 32459 , s. 22.

${ }^{35}$ BOA, D. BKL.d. 32459 , s. 22.

${ }^{36}$ Voyvoda; Slâvca bir kelime olup subaşı, ağa, reis gibi çeşitli anlamlara gelmektedir. Osmanlı Devleti'nde XVII. yüzyıldan itibaren eyalet valileri ile sancak mutasarrıflarının idaresine bırakılmış kazaların gediklerince veya halkın isteğiyle yerel bölgedeki birisi voyvoda seçilmektedir. Voyvodalar daha sonra kaza kaymakamlığı görevini de icra etmişledir. Pakalın, "Voyvoda", Osmanlı Tarih Deyimleri ve Terimleri Sözlüğü, C. III, s. 598.

${ }^{37}$ BOA, D. BKL.d. 32459, s. 24, 25.

${ }^{38}$ BOA, D. BKL. d. 32459, s. 24

${ }^{39}$ BOA, D. BKL.d. 32459, s. 24.

${ }^{40}$ BOA, D. BKL. d. 32459, s. 6- 25.
} 


\section{F.Ü. Sosyal Bilimler Dergisi 2013-24/1}

32.500 guruş etmiştir ${ }^{41}$. Hemedan Kalesi'nde bulunan bu 1000 kişilik süvari levendlerinin 7 Eylül 1730 (H. 23 Safer 1143) tarihinde Tebriz seraskeri Kaymakam İbrahim Paşa'nın maiyetine acilen katılmaları istenmiştir ${ }^{42}$.

1729- 1730 tarihleri arasında Hemedan Kalesi'ne 500 kişilik süvari levendinin görevlendirildiğini görmekteyiz. Bu süvari levendlerin kaydedilmesine Sadr-ı Âli Çukadarı Yusuf Paşa atanmıştır. 19 Temmuz 1730 tarihinde Bağdat Valisi Serasker Vezir Ahmet Paşa'nın marifetiyle Şehr-i Zor, Kerkük, Kürdistan ve sair ocaklık aşiret ve kabilelerinden temin edilmesi düşünülen bu 500 adet süvari levendinin toplanılmasından vazgeçilmiştir. Ayrıca bu süvari levendlerine ulûfe, bahşiş, zahire ve diğer mühimmat için verilen ücretlerinde seraskere teslim edilmesi istenmiş, bu konuda hem Çukadar Yusuf Paşa'ya hem de Serasker Ahmet Paşa'ya hitaben emirler verilmiştir. Bu süvari levendlerin toplanılmasından neden vazgeçildiği ile ilgili bir bilgiye sahip değiliz. Ancak, bunların başbuğluğuna Mustafa adında bir mütesellimin geçtiğini bilmekteyiz ${ }^{43}$.

Süvari levendleri 50'şer kişilik bayraklardan müteşekkil olup, toplamda 10 bayraktan meydana gelmekte idi. Ulûfe ve bahşişlerine baktığımızda; 500 süvari neferinin her birine aylık 2,5 guruşluk maaş bağlanılmıştır. 500 süvari levendinin tümüne aylık 1.250 guruş, 6 ayın sonunda ise 7.500 guruş verilmiştir. Bu ücrete ek olarak 750 guruş daha verilmiş ve böylece toplamda 8.250 guruş bir ödeme yapılmıştır. Bir defaya mahsus olmak üzere süvari levendlerinin her birine 20 guruş bahşiş verilmiş ve bahşişlerin toplam da 10.000 guruşa tekabül etmiştir ${ }^{44}$.

\section{Piyade ve Süvari Levendlerine Tahsis Edilen Zahire Miktarı ve Ücretleri}

Osmanlı Devleti savaşa katılacak askerlerinin asgari düzeydeki günlük beslenme ihtiyacını karşılamanın ordu içinde disiplin ve moral değerlerinin yükselteceğinin farkında olmuş ve askerlerin beslenmesine önem vermiştir ${ }^{45}$.

Osmanlı Devleti, savaş dönemlerinde kalenin savunma gücünü arttırmak maksadıyla askerin ve halkın uzun süre beslenebilmeleri için arpa, buğday, un, yem, odun, kömür gibi temel maddeler göndermiştir $^{46}$. Bu ürünler içerisinde buğday, arpa, bulgur, pirinç ve un gibi hububat ürünleri en önemli besin kaynağ $\mathrm{idi}^{47}$.

Osmanlı ordusuna verilen tayinatların başında ekmek ve peksimet gelmekteydi. Her ikisi de buğdaydan imal edilmesine rağmen farklı özelliklere sahipti. Peksimet, savaş esnasında ekmeğin pişirilmeye uygun bir zamanın olmadığ 1 durumlarda veya kıtlık dönemlerin de askerlerin ihtiyacını karşılayan ve uzun süre bozulmadan kalabilen bir gıda maddesidir. Ekmek ise peksimete göre pişirilmesi için yeterli zamanın ve alt yapının bulunduğu, savaş dönemlerinden uzak zamanlarda, sıcak bir şekilde tüketilen bir gıda maddesi olmuştur ve arşiv vesikalarında nan olarak yer almıştır ${ }^{48}$.

Et, 19. yüzyıla kadar ordu birliklerinin tüm zamanlarda tahıl ürünlerinin dışında tükettiği en önemli üründür ${ }^{49}$. Et, Osmanlı ordusunun en temel besin maddesi olmuş ve daha çok ordu

\footnotetext{
${ }^{41}$ BOA, D. BKL. d. 32459, s. 12

${ }^{42}$ BOA, D. BKL.d. 32459, s. 12.

${ }^{43}$ BOA, D. BKL.d. 32459, s. 16.

${ }^{44}$ BOA, D. BKL.d. 32459, s. 16.

${ }^{45}$ Rhoads Murphey, Osmanlıda Ordu ve Savaş 1500- 1700, (Çev. M. Tanju Akad ), İstanbul, 2007, s. 111.

${ }^{46}$ Mehmet Yaşar Ertaş, "Osmanlı Devletinde Sefer Organizasyonu”, Osmanlı, C. VI, Yeni Türkiye Yayınları, Ankara, 1999, s. 590.; Ömer İşbilir, "Savaş ve Bölgesel Ekonomi: İran Savaşlarında Doğu Karadeniz ve Doğu Anadolu”, Türkler, C. X, Ankara, 2002, s. 152.

${ }^{47}$ Mehmet Yaşar Ertaş, Sultanın Ordusu Mora Fethi Örneği 1714- 1716), İstanbul, 2007, s. 149.

${ }^{48}$ Ertaş, Sultanın Ordusu, s. 154; Pakalın, Osmanlı Tarih Deyimleri ve Terimleri Sözlüğü, C. II, s. 653.

${ }^{49}$ Ertaş, Sultanın Ordusu, s. 161.
} 
mensuplarına koyun eti verilmiştir ${ }^{50}$. Bu ihtiyacının karşılanması için mübaşirler görevlendirilmiştir ${ }^{51}$.

Arpa, askerleri ve bu askerler için gerekli erzakı, savaş, araç ve gereçlerini taşıyan yük hayvanlarının en önemli besin kaynağıdır ${ }^{52}$.

Hemedan Kalesi'ndeki piyade ve süvari levendlerin ihtiyaç duyduğu hububat ürünleri, arşiv vesikasında zahire başlığ 1 altında verilmiştirir ${ }_{55}^{53}$. Hemedan Kalesi'ne gidecek levendler için ekmek, et ve arpa, ${ }^{54}$ pirinç ve sade yağ dağıtılmıştır ${ }^{55}$.

Piyade ve süvari levendleri için peksimet yerine nan yani ekmek verilmiştir ${ }^{56}$. Piyade ve süvari levendlerin her birine günlük bir çift ekmek verilmiş ve bu miktar her iki askeri sınıf için de değişmemiştir. Günlük verilen et miktarında ise farklılıklar göze çarpmaktadır. Piyadelere günlük 0,5 kıyye et dağıtılmışken süvarilere ise 0,25 kıyye dağıtılmıştır ${ }^{57}$. Arpa miktarına baktığımızda; Diyarbakır'dan tahrir edilen 1000 piyade levendine bir günde 10 İstanbul kilesi, ${ }^{58}$ Anadolu'dan tahriri yapılan 500 adet piyade levendine 5 İstanbul kilesi, Mardin ve Diyarbakır'dan tahriri yapılan 2.000 piyade levendine ise 20 İstanbul kilesi arpa verilmiştir ${ }^{59} .1 .000$ kişilik süvari levendi için günlük verilen arpa miktarı 265 İstanbul kilesi ${ }^{60}, 500$ kişilik süvari levendi için 132,5 İstanbul kilesi olmuştur ${ }^{61}$.

Aşağıdaki tabloda piyade ve süvari levendlerine dağıtılan 90 günlük zahire miktarı verilmiştir.

Tablo 1:Hemedan Kalesi'ne Giden Piyade ve Süvari Levendlerin 90 Günlük Zahiresi (M. 1729- 1730/ H. 1142) ${ }^{62}$

\begin{tabular}{|c|c|c|c|c|c|}
\hline $\begin{array}{l}\text { Zahirenin } \\
\text { Cinsi }\end{array}$ & $\begin{array}{l}\text { Diyarbakır'dan } \\
\text { Hemedan'a Giden } \\
1000 \text { Piyade } \\
\text { Levendi }\end{array}$ & $\begin{array}{l}\text { Anadolu'dan } \\
\text { Hemedan'a } \\
\text { Giden } 500 \\
\text { Piyade Levendi }\end{array}$ & $\begin{array}{l}\text { Mardin ve } \\
\text { Diyarbakır'dan } \\
\text { Hemedan'a Giden } \\
\text { 2.000 Piyade } \\
\text { Levendi }\end{array}$ & $\begin{array}{l}\text { Hemedan'a } \\
\text { Giden } 500 \\
\text { Süvari levendi }\end{array}$ & $\begin{array}{l}\text { Hemedan'a } \\
\text { Giden 1.000 } \\
\text { Süvari } \\
\text { Levendi }\end{array}$ \\
\hline Ekmek & 90.000 çift & 45.000 çift & 180.000 çift & 45.000 çift & 90.000 çift \\
\hline $\mathrm{Et}$ & 45.000 k1yye & 22.500 k1yye & 90.000 k1yye & 11.250 k1yye & 22.500 k1yye \\
\hline Arpa & 900 İstanbul kilesi & 450 İstanbul kilesi & 1.800 İstanbul kilesi & $\begin{array}{l}11.925 \text { İstanbul } \\
\text { kilesi }\end{array}$ & $\begin{array}{l}23.850 \text { İstanbul } \\
\text { kilesi }\end{array}$ \\
\hline Pirinç & & & & 11.250 k1yye & 22.500 k1yye \\
\hline Sade yağ & & & & 2.812,5 k1yye & 5.625 k1yye \\
\hline
\end{tabular}

Tablo 1'de görüldüğ̈̈ üzere Hemedan Kalesi'ne gidecek piyade levendleri için ekmek, et ve arpa verilirken ${ }^{63}$; süvari levendleri için ekmek, et, arpadan başka pirinç ve sade yağ da verilmiştir. Süvarilere verilen Pirinç ile et aynı miktardadır. Piyadelere verilen et miktarı süvarilerin iki katıdır. Arpa miktarına baktığımızda ise süvarilere arpa miktarı piyadelerden 26,5 katıdır ${ }^{64}$. Süvarilere verilen arpanın piyadelere göre fazla olmasının sebebi süvari sınıfının sahip olduğu yük ve binek hayvanlarının piyadelerden daha fazla olmasıdır.

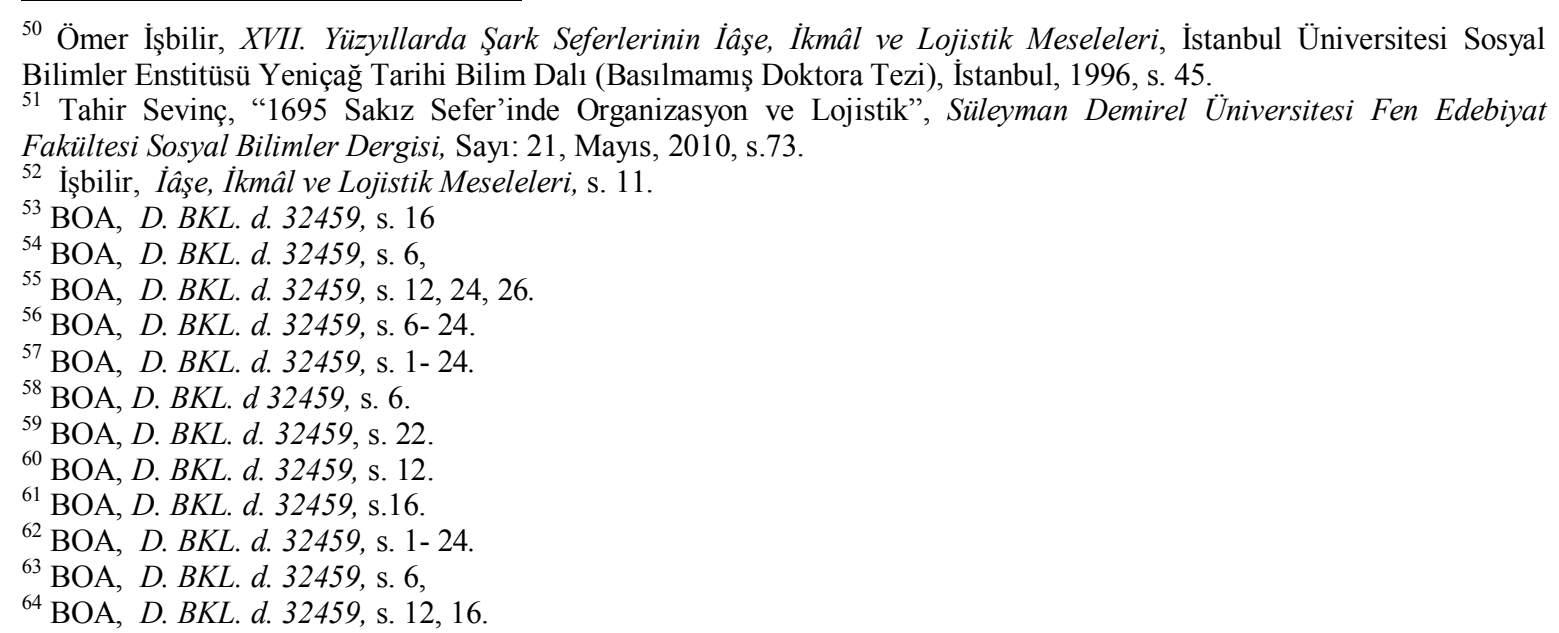




\section{F.Ü. Sosyal Bilimler Dergisi 2013-24/1}

Belgede Hemedan Kalesi'ne gidecek piyade ve süvari levendlerin zahire masrafinı öğrenmek mümkün olmuştur. Piyade ve süvari levendine günlük verilen 1 çift ekmeğe yapılan masraf 2 akçedir ve bu günlük masraf her iki askeri sınıfta da aynı olmuştur. Piyade ve süvari levendlerine verilen arpanın her bir İstanbul kilesine yapılan masraf 30 akçedir ${ }^{65}$. Ancak ete yapılan masrafta farklılıklar görülmektedir. Piyadelere günlük verilen 0,5 kıyye ete 5 akçe $^{66}$, süvarilere verilen 0,25 kıyye ete ise 3 akçe masraf yapılmıştır ${ }^{67}$. Yani süvarilere düşen et miktarı piyadelerin yarısı kadar; ancak yapılan masraf daha yüksektir. Muhtemelen süvarilere verilen etin cinsi piyadelere verilenlerden daha iyi idi.

Aşağıdaki tabloda Hemedan Kalesi’ne giden piyade ve süvarilerin 90 günlük zahire masrafları bir tablo halinde sunulmuştur.

Tablo 2: Hemedan Kalesi'ne Giden Piyade ve Süvari Levendlerin 90 Günlük Zahire Masrafı (M. 1729- 1730/ H. 1142)

\begin{tabular}{|c|c|c|c|c|c|}
\hline $\begin{array}{l}\text { Zahirenin } \\
\text { Cinsi }\end{array}$ & $\begin{array}{l}\text { Diyarbakır'dan } \\
\text { Hemedan'a Giden } \\
\text { 1000 Piyade Levendi }\end{array}$ & $\begin{array}{l}\text { Anadolu'dan } \\
\text { Hemedan'a } \\
\text { Giden 500 Piyade } \\
\text { Levendi }\end{array}$ & $\begin{array}{l}\text { Mardin ve } \\
\text { Diyarbakır'dan } \\
\text { Hemedan'a Giden } \\
\text { 2.000 Piyade Levendi }\end{array}$ & $\begin{array}{l}\text { Hemedan'a Giden } \\
500 \text { Süvari levendi }\end{array}$ & $\begin{array}{l}\text { Hemedan'a } \\
\text { Giden 1.000 } \\
\text { Süvari Levendi }\end{array}$ \\
\hline Ekmek & $\begin{array}{l}180.000 \text { akçe (15.000 } \\
\left.\text { guruş }{ }^{69}\right)\end{array}$ & $\begin{array}{l}90.000 \text { akçe (7.500 } \\
\text { guruş) }\end{array}$ & $\begin{array}{l}360.000 \text { akçe (30.000 } \\
\text { guruş) }\end{array}$ & $\begin{array}{l}90.000 \text { akçe ( } 7.500 \\
\text { guruş) }\end{array}$ & $\begin{array}{l}180.000 \text { akçe } \\
(15.000 \text { guruş })\end{array}$ \\
\hline Et & $\begin{array}{l}450.000 \text { akçe }(3.750 \\
\text { guruş) }\end{array}$ & $\begin{array}{l}225.000 \text { akçe } \\
(1.875 \text { guruş })\end{array}$ & $\begin{array}{l}900.000 \text { akçe }(7.500 \\
\text { guruş) }\end{array}$ & $\begin{array}{l}135.000 \text { akçe (1.125 } \\
\text { guruş) }\end{array}$ & $\begin{array}{l}270.000 \text { akçe } \\
(2.250 \text { guruş })\end{array}$ \\
\hline Arpa & 27.000 (225 guruş) & $\begin{array}{l}13.500 \text { akçe }(112,5 \\
\text { guruş) }\end{array}$ & 54.000 akçe (450 guruş) & $\begin{array}{l}357.500 \text { akçe ( } 2.979 \\
\text { guruş } 20 \text { akçe) }\end{array}$ & $\begin{array}{l}715.000(5.958 \\
\text { guruş } 40 \text { akçe) }\end{array}$ \\
\hline Pirinç & - & 年 & - & $\begin{array}{l}112.500 \text { akçe } \\
(937,5 \text { guruş })\end{array}$ & $\begin{array}{l}225.000 \text { akçe } \\
(1.875 \text { guruş })\end{array}$ \\
\hline Sade yağ & - & - & - & $\begin{array}{l}84.330 \text { akçe }(702,5 \\
\text { guruş } 30 \text { akçe })\end{array}$ & $\begin{array}{l}168.750 \text { akçe } \\
(1.405 \text { guruş } 30 \\
\text { akçe) }\end{array}$ \\
\hline \begin{tabular}{|l} 
Toplam \\
Zahire \\
Masrafi \\
\end{tabular} & $\begin{array}{l}657.000 \text { akçe (5.475 } \\
\text { guruş) }\end{array}$ & $\begin{array}{l}328.500 \text { akçe } \\
(2737,5 \text { guruş })\end{array}$ & $\begin{array}{l}\text { 1.314.000 akçe (37.950 } \\
\text { guruş) }\end{array}$ & $\begin{array}{l}779.330 \text { akçe }(6494 \\
\text { guruş } 50 \text { akçe) }\end{array}$ & $\begin{array}{l}1.558 .660 \text { akçe } \\
(12988,5 \text { guruş } \\
40 \text { akçe })\end{array}$ \\
\hline
\end{tabular}

Tablo 2'de görüldüğü üzere süvari levendine yapılan masraf piyadelere göre daha yüksektir. Bunun sebebi ise Piyade levendlerine verilmeyip, sadece süvari levendlerine verilen pirinç ve sade yağ ile arpa masrafının fazla olmasıdır. Süvari levendlerin her birine 0,25 kıyye pirinç dağıtılmış ve pirincin her bir kıyyesi için de 10 akçelik bir fiyat belirlenmiştir ${ }^{70}$.

Süvari levendlerine verilen diğer bir ürün ise sade yağ olmuştur. 1.000 süvari levendi için günlük verilen toplam sade yağ miktarı 62,5 kıyyedir. Her bir kıyyesi için 30 akçelik bir fiyat belirlenmiş ve günlük toplam masrafı da 1.875 akçe olmuştur. 500 adet süvari levendine günlük verilen sadeyağ miktarı da 32 kıyye 100 dirhemdir. Günlük yapılan toplam masraf 937 akçe olmuştur. 90 günün sonunda ise 84.330 akçelik bir masraf ortaya çıkmıştır ${ }^{71}$. Arpa miktarına baktığımızda ise süvarilere verilen arpa miktarı piyadelerin 26,5 katı olması yapılan masrafı daha da artırmıştır.

\section{Piyade ve Süvari Levendlerine Verilen Bargirler}

Askerlerin et ihtiyacının karşılanması, cephane ve mühimmatın taşınması ve askeri sevkıyatın sağlanması gibi durumlar için büyük miktarda $a t^{72}$, katır, deve $^{73}$, manda, inek, öküz, koyun v.b

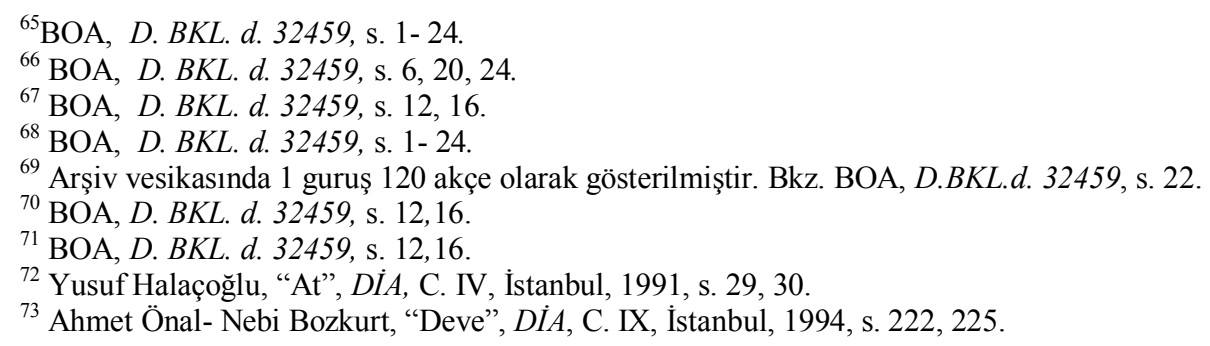


hayvanlara ihtiyaç duyulurdu ${ }^{74}$. Yolların bakımsız olduğu, araba ile nakillerin mümkün olmadığ1 elverişsiz, dağlik ve eğimli yerlerde bir takım taşıma işleri hayvan sırtında gerçekleşmekteydi ${ }^{75}$. Farklı türdeki binek hayvanları arazi ve iklim şartlarına göre değişmekle birlikte devlet, ihtiyaç duyduğu bu yük hayvanlarını ya kiralama, ya da satın alma yoluyla temin etmekteydi ${ }^{76}$.

Hemedan Kalesi'ne giden piyade ve süvari levendleri için çeşitli sayıda yük hayvanları verilmiştir. Piyade ve süvari levendlerine verilen yük hayvanlarının sayısında bir değişiklik olmamış; ancak masraflarda değişiklik görülmüş̧ür. Diyarbakır'dan temin edilen 1.000 kişilik piyade levendinin her bir bayrağındaki askerlere 3 bargir verilmiştir. Bir bayrak 50 askerden oluştuğuna göre 50 askere 3 yük hayvanı düşmüştür. Dolayısıyla 20 bayraktan oluşan bu levendlere toplamda 60 bargir verilmiştir. Bir defaya mahsus olmak üzere de her bir bargir için 15 guruşluk bir satın alma ücreti verilmiş ve 60 bargir için toplamda 900 guruşluk bir masraf yapılmıştır ${ }^{77}$.

Anadolu'dan temin edilen 500 nefer piyade levendi için her bir bayrağına 3 bargir düşmüş ve 10 bayrağa toplamda 30 bargir verilmiştir. Bu bargirlerin her birisine 15 guruşluk bir masrafla toplamda 450 guruş bir tutar ortaya çıkmıştır ${ }^{78}$.

Mardin ve Diyarbakır'dan tahriri yapılan ve 40 bayraktan oluşan 2.000 nefer piyade levendi için de toplam 120 bargir alınmış ve 15 guruşluk bir masrafla toplam 18.000 guruş bir ücret verilmiştir $^{79}$. Hemedan Kalesi'ne giden piyade levendlerinin her bir bayrağına verilen 3 adet bargir sayısında ve her bir bargir için verilen 15 guruşluk bir ücrette değişiklik olmamıştır.

Piyade levendlerinde olduğu gibi süvari levendlerine de çeşitli bargirler verilmiştir. Arşiv belgesinde Süvari levendlerinde bargirlerin hangi tür işlerde kullanıldığı belirtilmiş; ancak piyade levendlerinde bu bilgi yer almamıştır. Süvari levendlerine verilen bargirlerin su taşıyan saka bargirleri ${ }^{80}$ ile üzerine yük ve yolcunun da bindiği sâyis- hâne $e^{81}$ olarak geçen bargirler mevcuttur. 1000 adet süvari levendine 20 adet saka ve 40 adet sâyis- hâne bargiri verilmiştir. Bu bargilerin her biri için 30 guruşluk bir fiyat belirlenmiş ve 1.800 guruş bir masraf ortaya çıkmıştır ${ }^{82}$. 500 kişilik süvari levendi için 10 adet saka bargiri ve 20 adet sâyis- hâne olmak üzere toplam 30 adet bargir verilmiş ve her bir bargir için de 30 guruşluk bir masraf ortaya çıkmıştır. 30 bargir için toplamda 900 guruşluk bir ödeme yapılmıştır ${ }^{83}$. Süvari levendlerine verilen bargirler için 30 guruş, piyade levendlerine verilen bargirlere ise 15 guruşluk bir masraf yapılmıştır. Piyadelere verilen bargilerin ne tür bir bargir olduğu bilgisi yer almadığı için bu fiyat farkının neden ileri geldiği konusunda her hangi bir bilgiye sahip değiliz. Ancak süvari levendlerine verilen bargirlere daha fazla masraf yapılması bu bargirlerin piyade levendlerinkine göre daha kıymetli olduğu anlaşılmaktadır.

\section{Piyade ve Süvari Levendlere Verilen Mühimmat}

Hemedan Kalesi'ne giden piyade ve süvari levendleri için çeşitli mühimmat ve bakırdan ev eşyaları verilmiştir. $\mathrm{Bu}$ araç- gereçlerin hem miktarını hem de yapılan masrafları öğrenmek mümkündür. Verilen mühimmat içinde en başta gelen sekban çergesidir. Diğer mühimmatı ise çadır, çeşme, un çuvalı, demir saç, at eğeri için kullanılan kantarma, kazgan, lengerin, kapağı ile birlikte tencere ve kevgir kefçesidir.

Kazgan, lengerin, tencere, kefçe kevgiri bakırdan imal edilmiş eşyalardı. Kazganın ağırlığ 5 kıyye, lengerinin 3 kıyye, tencerenin ve kefçe kevgirinin ağırlı̆̆ ise 2 kıyye idi ${ }^{84}$.

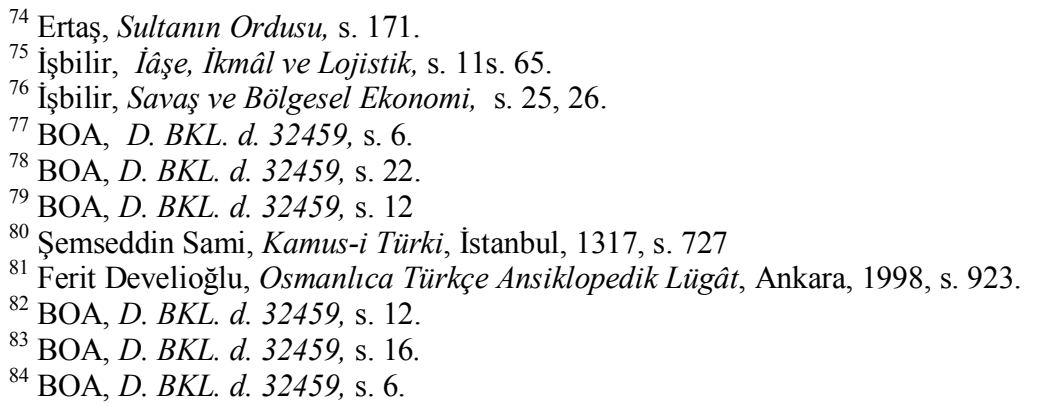




\section{F.Ü. Sosyal Bilimler Dergisi 2013-24/1}

Tablo 3: Hemedan Kalesi’ne Piyade ve Süvari Levendlerine Verilen Mühimmat (M.1729- 1730/ H. 1142) ${ }^{85}$

\begin{tabular}{|c|c|c|c|c|c|}
\hline $\begin{array}{l}\text { Mühimmatın } \\
\text { Cinsi }\end{array}$ & $\begin{array}{l}\text { Diyarbakır'dan } \\
\text { Hemedan'a Giden } \\
1000 \text { Piyade } \\
\text { Levendi }\end{array}$ & $\begin{array}{l}\text { Anadolu'dan } \\
\text { Hemedan'a } \\
\text { Giden 500 } \\
\text { Piyade Levendi }\end{array}$ & $\begin{array}{l}\text { Mardin ve } \\
\text { Diyarbakır'dan } \\
\text { Hemedan'a Giden } \\
\text { 2.000 Piyade } \\
\text { Levendi }\end{array}$ & $\begin{array}{l}\text { Hemedan'a } \\
\text { Giden 500 } \\
\text { Süvari levendi }\end{array}$ & $\begin{array}{l}\text { Hemedan'a } \\
\text { Giden 1.000 } \\
\text { Süvari } \\
\text { Levendi }\end{array}$ \\
\hline Sekban Çergesi ${ }^{86}$ & 20 adet & 10 adet & 40 adet & 10 adet & 20 adet \\
\hline Çadır & 20 adet & 10 adet & 40 adet & 10 adet & 20 adet \\
\hline Çeşme & 20 adet & 10 adet & 40 adet & 10 adet & 20 adet \\
\hline Un çuval1 & 60 çift & 30 çift & 120 çift & 20 çift & 40 çift \\
\hline Demir Saç & 20 adet & 10 adet & 40 çift & & \\
\hline Kazma & 20 adet & 10 adet & 40 adet & & \\
\hline Kazan & 30 adet & 15 adet & 60 adet & $\overline{10}$ adet & $\overline{20}$ adet \\
\hline Lengerin & 40 adet & 20 adet & 80 adet & 20 adet & 40 adet \\
\hline Tencere & 30 adet & 15 adet & 60 adet & 10 adet & 20 adet \\
\hline Kefçe Kevgiri & 20 çift & 10 çift & 40 çift & 10 çift & 20 çift \\
\hline Meşk & & & & 10 çift & 20 çift \\
\hline Maslak & & & & 10 adet & 20 adet \\
\hline Saka semeri & & & & 30 adet & 60 adet \\
\hline
\end{tabular}

Tablo 3'te Piyade ve süvari levendlerine verilen mühimmat miktarının nefer sayısına paralel olarak artış gösterdiği görülmektedir. 2.000 nefer piyade levendine verilen sekban çergesi, çadır, çeşme, un çuvalı, demir saç, kazma, kazgan, lengerin, tencere ve kefçe kevgirinin miktarı 1.000 piyade levendinin iki katıdır. Süvari levendlerinde de benzer durum görülmektedir. 1.000 nefer süvari levendine verilen mühimmat miktarı 500 nefer süvari levendinin iki katıdır.

Süvari levendlerin su ihtiyacının karşılanması için mükemmel meşk ve maslaklar temin edilmiştir. Meşk, büyük su kalıbı olup sefer sırasında askerlerin su ihtiyacının karşılanması için satın alınmıştır ${ }^{87}$. Meşk, maslak ve saka semeri süvarilere verilmişken piyadelere verilmemiştir.

Tablo 4: Hemedan Kalesi'ne Piyade ve Süvari Levendlerinin Mühimmat Masrafi (M. 1729- 1730/ H. 1142)

\begin{tabular}{|c|c|c|c|c|c|}
\hline $\begin{array}{l}\text { Mühimmatın } \\
\text { Cinsi }\end{array}$ & $\begin{array}{l}\text { Diyarbakır'dan } \\
\text { Hemedan'a Giden } \\
1000 \text { Piyade } \\
\text { Levendi }\end{array}$ & $\begin{array}{l}\text { Anadolu'dan } \\
\text { Hemedan'a } \\
\text { Giden 500 } \\
\text { Piyade Levendi }\end{array}$ & $\begin{array}{l}\text { Mardin ve } \\
\text { Diyarbakır'dan } \\
\text { Hemedan'a Giden } \\
\text { 2.000 Piyade } \\
\text { Levendi }\end{array}$ & $\begin{array}{l}\text { Hemedan'a } \\
\text { Giden 500 } \\
\text { Süvari levendi }\end{array}$ & $\begin{array}{l}\text { Hemedan'a } \\
\text { Giden 1.000 } \\
\text { Süvari } \\
\text { Levendi }\end{array}$ \\
\hline Sekban Çergesi & 500 guruş & 250 guruş & 1.000 guruş & 300 guruş & 600 guruş \\
\hline Çadır & 340 guruş & 170 guruş & 680 guruş & 150 guruş & 300 guruş \\
\hline Çeşme & 60 guruş & 30 guruş & 120 guruş & 30 guruş & 60 guruş \\
\hline Un çuvalı & 90 guruş & 45 guruş & 180 guruş & 30 guruş & 60 guruş \\
\hline Demir Saç & 20 guruş & 10 guruş & 40 guruş & & \\
\hline Kazma & 6,5 guruş 20 akçe & 3 guruş & 10 guruş & & \\
\hline Kazan & 150 guruş & 75 guruş & 300 guruş & $\overline{75}$ guruş & $\overline{150 \text { guruş }}$ \\
\hline Lengerin & 180 guruş & 90 guruş & 360 guruş & 90 guruş & 180 guruş \\
\hline Tencere & 90 guruş & 45 guruş & 180 guruş & 45 guruş & 90 guruş \\
\hline Kefçe Kevgiri & 60 guruş & 30 guruş & 120 guruş & 22,5 guruş & 45 guruş \\
\hline Meşk & & & & 100 guruş & 200 guruş \\
\hline Maslak & & & & 65 guruş & 130 guruş \\
\hline Saka semeri & & & & 45 guruş & 90 guruş \\
\hline Toplam & $\begin{array}{l}\text { 1.496,5 guruş } 20 \\
\text { akçe }\end{array}$ & $\overline{748 \text { guruş }}$ & 2.990 guruş & 952.5 guruş & 1.905 guruş \\
\hline
\end{tabular}

\footnotetext{
${ }^{85}$ BOA, D. BKL. d. 32459, s. 1- 24.

${ }^{86}$ Sekban Çergesi; Farsça bir kelime olup, hafif çadır demektir. Hafif oba, iki direkli şemsiye anlamına gelen bu çadırlarını Osmanlı ordusunda sekban bölükleri kullanmıştır. Ahmet Vefik Paşa, Lehçe-i Osmânî, s. 94; Pakalın, Osmanlı Tarih Deyimleri ve Terimleri Sözlüğ̈̈, C. I, s. 353.

${ }^{87}$ Tahir Sevinç, “17. Yüzyıl Sonlarında Başarısız Bir Sefere Girişimi: 1695 Mora Seferi”, History Studies, Volume, 2/ 3, 2010, s. 292.

${ }^{88}$ BOA, D. BKL. d. 32459, s. 1- 24.
} 
Tablo 4'de Hemedan Kalesi'nin muhafazası için Mardin ve Diyarbakır'dan temin edilen 2.000 piyade levendine daha fazla mühimmat masrafi yapılmıştır. Bunun sebebi ise nefer sayısının diğerlerine göre fazla olmasıdır. 500 nefer süvari neferine yapılan masraf 500 nefer piyade neferine yapılan masraftan daha fazladır. Her iki askeri sınıfın sayılarının aynı olmasına rağmen yapılan masrafin süvarilerde fazla olmasının sebebi ise meşk, maslak ve saka semerinin piyadelere verilmemesidir.

\section{Piyade ve Süvari Levendlerine Yapılan Toplam Masraflar}

Belgelerden Hemedan Kalesi'ne nakledilen süvari ve piyade levendlerin ulûfe, bahşiş, zahire, bargir ve mühimmat ile ilgili yapılan tüm masraflarını öğrenmek de mümkündür. Bu masrafları nereden karşılandığı kısmen de belirtilmiştir. Diyarbakır'dan Hemedan Kalesine gönderilen 1.000 piyade neferinin tüm masrafları $36.626,5$ guruş ve 20 akçedir $^{89}$. Anadolu'un muhtelif yerlerinden gönderilen 500 piyade levendi için yapılan toplam masraf 18.318 guruş ve 1 paradır ${ }^{90}$. Diyarbakır ve Mardin'den Hemedan Kalesi'ne gönderilen 2.000 nefer piyade levendi için yapılan toplam masraf 70.250 guruştur. $\mathrm{Bu}$ miktarın 4.860 guruşu Mardin hazinesinden, 15.389,5 guruşu Diyarbakır voyvodalığından, 50.000 guruşu da İstanbul'dan karşılanacağı belirtilmiştir ${ }^{91}$.

Piyade levendlerine yapılan tüm masraflarına baktığımızda; 1.000 adet süvari levendinin tümü için yapılan masraf 53.393,5 guruş 1 akçedir. $^{92} 500$ adet süvari levendine ise toplam yapılan masraf 26.696,5 guruş 15 paradır $^{93}$.

Hemedan Kalesi'ne daha çok piyade askerlerinin görev aldığını görmekteyiz. Bunun en önemli sebebi ise süvari levendlerinin devlete olan külfetinin fazla olmasındandır ${ }^{94}$.

Süvari levendlerine yapılan masrafla piyade levendlerine yapılan masrafi karşılaştırdığımızda, süvari levendlerine daha fazla miktarda harcama yapıldığı görülmektedir. 500 nefer Piyade levendine 18.318 guruş ve 1 para masraf yapılırken; 500 nefer süvari levendine ise $26.696,5$ guruş ve 15 para masraf yapılmıştır ${ }^{95} .1000$ nefer piyade neferine $36.626,5$ guruş 20 akçe masraf yapılmış iken; 1000 adet süvari levendine ise 53.393,5 guruş 1 akçe masraf yapılmıştır. ${ }^{96}$. Bunun sebebi ise süvarilere daha fazla bahşiş, zahire, mühimmat ve bakırdan yapılmış ev eşyası ile daha masraflı bargirlerin verilmesidir.

\section{SONUÇ}

Hemedan, jeopolitik konumu nedeniyle Osmanlı- İran savaşlarının yaşandığı 18. yüzyılın ilk yarısında sürekli el değiştirmiştir. Osmanl- İran savaşlarının yoğun geçtiği 1729- 1730 tarihleri arasında, Hemedan Kalesi'nin ihtiyaç duyduğu piyade ve süvari levendleri, Anadolu'nun muhtelif yerlerinden özellikle de Güney Doğu Anadolu'da Diyarbakır, Mardin ve Kilis gibi yerlerden temin edilmiştir. Bu yerlerden temin edilme sebebi ise, Osmanlı- İran savaşlarında bölgenin coğrafi ve jeopolitik açıdan çok önemli askeri ve lojistik bir güç olmasından kaynaklanmaktadır.

Temin edilen ve Bağdat Valisi Hemedan seraskeri Ahmet Paşa'nın maiyetine verilen piyade ve süvari levendleri bir bayrak ünitesi içerisinde 50' şer kişilik gruplar halinde bulunmuş ve bu askerlerin ulûfe, bahşiş, zahire, mühimmat ve bargir gibi ihtiyaçları da bayrak birimine göre hesaplanarak verilmiştir.

Hemedan Kalesi'ne gidecek piyade levendleri süvari levendlerine göre daha fazladır. Süvari levendlerinin piyade levendlerine göre daha masraflı olduğu tespit edilmiştir. Dolayısıyla Hemedan

\footnotetext{
${ }^{89}$ BOA, D. BKL. d. 32459, s. 6.

${ }^{90}$ BOA, D. BKL. d. 32459, s. 22.

${ }^{91}$ BOA, D. BKL.d. 32459, s. 24.

${ }^{92}$ BOA, D. BKL. d. 32459, s. 12.

${ }^{93}$ BOA, D. BKL.d. 32459, s. 16.

${ }^{94}$ Murphey, s. 75; Sevinç, "Mora Seferi”, s. 288.

${ }^{95}$ BOA, D. BKL. d. 32459, s. 22, 16.

${ }^{96}$ BOA, D. BKL. d. 32459 , s. 6, 16.
} 


\section{F.Ü. Sosyal Bilimler Dergisi 2013-24/1}

Kalesi'ne daha fazla sayıda piyade levendi gönderilmiştir. Hemedan Kalesi’ne giden süvari ve piyade levendleri Hemedan Kalesi'nde başarılı olmuş ve bu kale bir müddet sonra İran'dan alınmıştır. Ancak Hemedan Kalesi Osmanlı egemenliğinde uzun süre kalamamış ve Nadir, Hemedan Kalesi'ni tekrar İran topraklarına katmıştır.

\section{KAYNAKÇA}

\section{Arşiv Kaynaklar}

(Bab-ı Defteri Büyük Kale Kalemi) BOA, D. BKL.

No: 32459.

\section{Araştırma ve İnceleme Eserleri} 2000

AHMET VEFIK PAŞA, Lehçe-i Osmani, Türk Dil Kurumu Yayınları ( Haz. Recep Toparlı) Ankara,

KÜÇÜK ÇELEBİZÂDE İSMAİL Asım, Asım Tarihi, İstanbul, 1284

MÜTERCIM ÂSIM EFENDİ, Burhân-ı Katı, ( Çev. Mürsel Öztürk, Deya Örs), Türk Dil Kurumu Yayınları, Ankara, 2009

ŞEMSEDDIN SAMI, Kamus-i Türki, İstanbul, 1317.

ŞEM'DÂNÎ- ZADE FINDIKLILI SÜLEYMAN EFENDİ, Mür'i't Tevârih, C. I, (Haz. Münir Aktepe), İstanbul, 1976,

AKDAĞ, Mustafa, Türkiye'nin İktisadî ve İçtimaî Tarihi (1453- 1559), C. II, Ankara, 1999.

; Celali İsyanlarl, Ankara, 1999, s. 153- 170

AKTEPE, Münir, 1720- 1724 Osmanll- İran Münasebetleri ve Silahşör Kemânî Mustafa Ağa'nın Revan Fetih-nâmesi, İstanbul, 1970.

'Nadir Şah'ın Osmanlı Padişahı I. Mahmud'a Gönderdiği Taht-1 Tavus Hakkında", Tarih Dergisi, Say1: 28- 29, İstanbul, 1975, s. 113- 122.

AKGÜNDÜZ, Ahmet, Osmanlı Kanunnameleri ve Hukuki Tahlilleri, C. V, İstanbul, 1992. Osmanlı Kanunnameleri ve Hukuki Tahlilleri, C. V, İstanbul, 1992.

BALA, Mirza, "Hemedân”, İA, C. 5/1, Eskişehir, 2001, s. 420- 425.

CEZAR, Mustafa, Osmanlı Tarihinde Levendler, İstanbul, 1965, s. 345

CL. HUART, "Bahşış", İA, C. II, Milli Eğitim Basımevi, İstanbul, 1979.s. 238.

DEVELIOĞLU, Ferit, Osmanlıca Türkçe Ansiklopedik Lügât, Ankara, 1998.

HAMMER, Joseph Von, Büyük Osmanlı Tarihi, C. VII, ( Çev. Vecdi Bürün), İstanbul, 1991

HALAÇOĞLU, Yusuf, “At”, DİA, C. IV, İstanbul, 1991, s. 29- 30.

İLGÜREL, Mücteba, "Levend”, DIA, C. XXVII, Ankara, s. 149- 151.

İŞBILİR, Ömer; XVII. Yüzylllarda Şark Seferlerinin İâse, İkmâl ve Lojistik Meseleleri, İstanbul Üniversitesi Sosyal Bilimler Enstitüsü Yeniçağ Tarihi Bilim Dalı Basılmamış Doktora Tezi, İstanbul, 1996. , "Savaş ve Bölgesel Ekonomi: İran Savaşlarında Doğu Karadeniz ve Doğu

Anadolu”, Türkler, C. X, Ankara, 2002, s. 19- 40.

IVECAN, Raif, Osmanl Hâkimiyetinde Revan (1724- 1746), Marmara Üniversitesi Türkiyat Araştırmaları Enstitüsü Türk Tarihi Anabilim Dalı Yeniçağ Tarihi Bilim Dalı, Basılmamış Doktora Tezi, İstanbul, 2007.

JOHANN WILHELM ZINKEISEN, Osmanlı İmparatorluğu Tarihi, C. V, İstanbul, 2011.

KIRZIOĞLU, Fahrettin, Kars Tarihi, İstanbul, 1953. 
KILIÇ, ORHAN, 18. Yüzyılın Illk Yarısında Osmanlı Devleti'nin İdari Taksimatı Eyalet ve Sancak Tevcihat , Elazı $\breve{g}, 1997$.

KULBİLGE, İlker, 18. Yüzyllın İlk Yarısında Osmanll- Iran Siyasi İlişkileri (1703- 1747), Ege Üniversitesi Sosyal Bilimler Enstitüsü Tarih Anabilim Dalı Yeniçağ Tarihi Bilim Dalı Basılmamış Doktora Tezi, İzmir, 2010.

KURTARAN, Uğur, "Yeni Kaynakların Işı̆̆ıında Sultan I. Mahmud Dönemi Osmanlı İran İlişkileri (1731- 1747)”, History Studies, Volume 3/3, 2011, s.177- 213.

ÖNAL, Ahmet- Nebi Bozkurt, "Deve”, DİA, C. IX, İstanbul, 1994, s. 222- 225.

PAKALIN, Mehmet Zeki, Osmanlı Tarih Deyimleri ve Terimleri Sözlüğ̈̈, C. I, II, III, Milli Eğitim Basımevi, İstanbul 1983.

RHOADS MURPHEY, Osmanlıda Ordu ve Savaş 1500- 1700, (Çev. M. Tanju Akad ), İstanbul, 2007.

SERTOĞLU, Mithat, Osmanlı Tarih Lügâtı, Ankara, 1999,

SEVINÇ, Tahir, "17. Yüzyıl Sonlarında Başarısız Bir Sefere Girişimi: 1695 Mora Seferi”, History Studies, Volume, 2/ 3, 2010, s. 285- 306.

, “1695 Sakız Sefer'inde Organizasyon ve Lojistik”, Süleyman Demirel Üniversitesi Fen Edebiyat Fakültesi Sosyal Bilimler Dergisi, Sayı: 21, Mayıs, 2010, s.59- 79.

V. MINORSKY, "Nadir”, İA, C. IX, Milli Eğitim Bakanlığı Devlet Kitapları, Eskişehir, 2001, s.21- 31.

Uzunçarşılı, İsmail Hakkı, Osmanlı Tarihi, C. IV, Türk tarih Kurumu Basımevi, Ankara, 1999.

YAZICI, Tahsin, "Hemedân”, DİA, C. XVII, İstanbul, 1988, s. 183- 185. 
